\title{
FAKTOR-FAKTOR YANG MEMPENGARUHI DISCRETIONARY LOAN LOSS PROVISIONS PADA PERUSAHAAN PERBANKAN YANG TERDAFTAR DI BURSA EFEK INDONESIA
}

\author{
Sofia Prima Dewi dan Eveline \\ Fakultas Ekonomi Universitas Tarumanagara Jakarta \\ Email: sofia_primadewi@yahoo.com
}

\begin{abstract}
The purpose of this study was to obtain empirical evidence about the effect of earnings before tax and provisions, the quality of voluntary disclosure, needs for external financing, other alternatives to earnings management, and firm size to discretionary loan loss provisions in banking companies listed in Indonesia Stock Exchange. The samples used were 26 banking companies listed in Indonesia Stock Exchange during 2011-2013. Data analysis was performed with the aid of a software program Statistical Product and Service Solutions (SPSS) for Windows version 20. The results showed that earnings before tax and provisions have an influence on discretionary loan loss provisions, while the quality of voluntary disclosure, needs for external financing, other alternatives to earnings management, and firm size does not have any influence on discretionary loan loss provisions.
\end{abstract}

Key words: earnings before tax and provisions, the quality of voluntary disclosure, needs for external financing, other alternatives to earnings management, firm size, discretionary loan loss provisions

Abstrak: Tujuan penelitian ini adalah untuk mendapatkan bukti empiris mengenai pengaruh earnings before tax and provisions, kualitas pengungkapan sukarela, kebutuhan pendanaan eksternal, alternatif lain untuk manajemen laba, dan ukuran perusahaan terhadap discretionary loan loss provisions pada perusahaan perbankan yang terdaftar di Bursa Efek Indonesia. Sampel yang digunakan adalah 26 perusahaan perbankan yang terdaftar di Bursa Efek Indonesia selama tahun 2011-2013. Analisis data dilakukan dengan bantuan program software Statistical Product and Service Solution (SPSS) for Windows versi 20. Hasil penelitian menunjukkan bahwa earnings before tax and provisions memiliki pengaruh terhadap discretionary loan loss provisions, sedangkan kualitas pengungkapan sukarela, kebutuhan pendanaan eksternal, alternatif lain untuk manajemen laba, dan ukuran perusahaan tidak memiliki pengaruh terhadap discretionary loan loss provisions.

Kata kunci: earnings before tax and provisions, kualitas pengungkapan sukarela, kebutuhan pendanaan eksternal, alternatif lain untuk manajemen laba, ukuran perusahaan, discretionary loan loss provisions

\section{PENDAHULUAN}

Salah satu tulang punggung perekonomian suatu negara adalah lembaga perbankan karena lembaga ini mengemban fungsi utama sebagai perantara keuangan antara kreditur (pihak-pihak yang memiliki dana) dengan debitur (pihak-pihak yang memerlukan dana) 
serta sebagai lembaga yang berfungsi memperlancar aliran lalu lintas pembayaran. Industri perbankan Indonesia telah mengalami pasang surut baik yang mendorong pertumbuhan ekonomi maupun yang menghambat pertumbuhan ekonomi.

Krisis keuangan yang terjadi di Asia pada tahun 1998 dan imbas dari krisis global di Amerika pada tahun 2008 membuat Basel Committee on Banking Supervision mengeluarkan Basel III: A Global Regulatory Framework for More Resilient Banks and Banking Systems pada bulan Desember 2010 yang salah satu tujuannya adalah memperbaiki kualitas dan kuantitas modal perusahaan perbankan dengan cara meningkatkan transparansi dan keterbukaan. Imbas krisis di kawasan Eropa yang terjadi pada tahun 2011 membuat Basel Committee on Banking Supervision merevisi Basel III: A Global Regulatory Framework for More Resilient Banks and Banking Systems pada bulan Juni 2011. Pengalaman krisis di atas merupakan pengalaman yang sangat berharga untuk memperbaiki kualitas industri perbankan Indonesia agar lebih mempunyai daya tahan pada kondisi krisis.

Media komunikasi yang digunakan untuk menghubungkan pihak-pihak yang berkepentingan terhadap perusahaan perbankan adalah laporan keuangan. Informasi yang terdapat dalam laporan keuangan dapat memberikan gambaran kinerja perusahaan perbankan dan salah satu parameter yang digunakan untuk mengukur kinerja perusahaan perbankan adalah informasi mengenai laba. Informasi laba haruslah menggambarkan keadaan ekonomi dan keuangan perusahaan perbankan yang sebenarnya karena akan digunakan oleh para pengguna laporan keuangan baik pihak internal maupun eksternal dalam pengambilan keputusan. Pada kenyataannya informasi laba ini justru seringkali menjadi target rekayasa pihak manajemen untuk memaksimalkan kepuasan mereka sendiri. Tindakan manajemen untuk merekayasa dan mengatur laba sesuai dengan keinginan mereka dikenal dengan istilah manajemen laba (earnings management). Menurut Sanjaya (2011: 61) fenomena manajemen laba di Indonesia telah banyak ditemukan. Menurut Yang et al. (2014: 38) manajemen laba terjadi karena manajer mengatur laba untuk meningkatkan kompensasi mereka. Menurut Shin dan Wang (2012: 27) kompensasi yang diinginkan manajer adalah bonus tahunan. Salah satu bentuk manajemen laba adalah perataan laba. Menurut Norden dan Stoian (2013: 26) perusahaan perbankan menggunakan discretionary loan loss provisions untuk meratakan labanya.

Penelitian mengenai faktor-faktor yang mempengaruhi discretionary loan loss provisions telah banyak dilakukan namun menunjukkan hasil yang tidak konsisten. Penelitian Kanagaretnam, et al. (2003), Perez, et al. (2006), Kwak, et al. (2009), Dong, et al. (2012), serta Syahfandi dan Mutmainah (2012) menunjukkan bahwa earnings before tax and provisions memiliki pengaruh terhadap discretionary loan loss provisions. Penelitian Taktak, et al. (2010) menunjukkan bahwa earnings before tax and provisions tidak memiliki pengaruh terhadap discretionary loan loss provisions. Penelitian Sanjaya dan Young (2012) menunjukkan bahwa kualitas pengungkapan sukarela memiliki pengaruh terhadap discretionary loan loss provisions sedangkan penelitian Ginting (2013) menunjukkan bahwa kualitas pengungkapan sukarela tidak memiliki pengaruh terhadap discretionary loan loss provisions.

Penelitian Kwak, et al. (2009) menunjukkan bahwa kebutuhan pendanaan eksternal memiliki pengaruh terhadap discretionary loan loss provisions sedangkan penelitian Tobing dan Anggorowati (2009) menunjukkan bahwa kebutuhan pendanaan eksternal tidak memiliki pengaruh terhadap discretionary loan loss provisions. Penelitian Kwak, et 
al. (2009) menunjukkan bahwa alternatif lain untuk manajemen laba memiliki pengaruh terhadap discretionary loan loss provisions sedangkan penelitian Kanagaretnam, et al. (2003) menunjukkan bahwa alternatif lain untuk manajemen laba tidak memiliki pengaruh terhadap discretionary loan loss provisions.

Penelitian Taktak, et al. (2010) serta Syahfandi dan Mutmainah (2012) menunjukkan bahwa ukuran perusahaan memiliki pengaruh terhadap discretionary loan loss provisions sedangkan penelitian Perez, et al. (2006) dan Kwak, et al. (2009) menunjukkan bahwa ukuran perusahaan tidak memiliki pengaruh terhadap discretionary loan loss provisions. Ketidakkonsistensian hasil-hasil penelitian di atas menjadi latar belakang untuk dilakukannya kembali penelitian mengenai pengaruh earnings before tax and provisions, kualitas pengungkapan sukarela, kebutuhan pendanaan eksternal, alternatif lain untuk manajemen laba, dan ukuran perusahaan terhadap discretionary loan loss provisions.

\section{KAJIAN TEORI}

Discretionary Loan Loss Provisions. Menurut Ginting dan Haryanto (2016: 3) manajer bank menggunakan loan loss provisions untuk mengukur kekuatan finansial bank dan sebagai salah satu acuan bank menentukan sikap dalam pengendalian risiko kredit perbankan. Menurut Zoubi dan Al-Khazali (2007) loan loss provisions telah menjadi alat untuk perataan laba di dunia perbankan. Menurut Norden dan Stoian (2013: 26) perusahaan perbankan menggunakan loan loss provisions untuk meratakan labanya karena loan loss provisions merupakan salah satu akun akrual yang dapat dimanipulasi oleh perusahaan sehingga laba dapat menjadi lebih tinggi atau rendah. Perusahaan dapat memanfaatkan unsur subyektivitas dalam membuat estimasi penilaian loan loss provisions.

Menurut Isa (2013: 814) loan loss provisions adalah: "A method that banks use to recognize a reduction in the realizable value of their loans." Menurut Dong, et al. (2012: 172) loan loss provisions terdiri dari dua komponen yaitu non discretionary loan loss provisions dan discretionary loan loss provisions. Menurut Astuti (2007: 1) komponen non discretionary merupakan penurunan aset keuangan yang terjadi secara alami (seperti biaya depresiasi) sedangkan komponen discretionary merupakan penurunan aset keuangan akibat kebijakan manajemen. Menurut Ikatan Akuntan Indonesia (2012: 55.19) Pernyataan Standar Akuntansi Keuangan 55 paragraf 65 entitas diwajibkan untuk mengevaluasi apakah terdapat bukti obyektif bahwa aset keuangan atau kelompok aset keuangan mengalami penurunan nilai pada setiap akhir periode pelaporan.

Berdasarkan Peraturan Bank Indonesia Nomor 14/ 15/ PBI/ 2012 tentang penilaian kualitas aset bank umum pasal 41 ayat (1), bank wajib menghitung penyisihan penghapusan aset terhadap aset produktif dan aset non produktif. Berdasarkan Peraturan Bank Indonesia Nomor 14/ 15/ PBI/ 2012 tentang penilaian kualitas aset bank umum pasal 1 ayat (3), pengertian aset produktif adalah:

"Penyediaan dana bank untuk memperoleh penghasilan, dalam bentuk kredit, surat berharga, penempatan dana antar bank, tagihan akseptasi, tagihan atas surat berharga yang dibeli dengan janji dijual kembali (reverse repurchase agreement), tagihan derivatif, penyertaan, transaksi rekening administratif serta bentuk penyediaan dana lainnya yang dapat dipersamakan dengan itu." 
Berdasarkan Peraturan Bank Indonesia Nomor 14/ 15/ PBI/ 2012 tentang penilaian kualitas aset bank umum pasal 1 ayat (4), pengertian aset non produktif adalah: "Aset bank selain aset produktif yang memiliki potensi kerugian, antara lain dalam bentuk agunan yang diambil alih, properti terbengkalai (abandoned property), rekening antar kantor, dan suspense account."

Berdasarkan Peraturan Bank Indonesia Nomor 14/ 15/ PBI/ 2012 tentang penilaian kualitas aset bank umum pasal 41 ayat (1), bank diwajibkan menghitung penyisihan penghapusan aset baik untuk aset produktif maupun aset non produktif dalam rangka memenuhi prinsip kehati-hatian. Sesuai dengan standar akuntansi keuangan yang berlaku, hasil perhitungan penyisihan penghapusan aset tidak dicatat dalam laporan keuangan bank. Perhitungan penyisihan penghapusan aset terhadap aset non produktif dimaksudkan pula untuk mendorong bank melakukan upaya penyelesaian dan untuk antisipasi terhadap potensi kerugian.

Berdasarkan Peraturan Bank Indonesia Nomor 14/ 15/ PBI/ 2012 tentang penilaian kualitas aset bank umum pasal 41 ayat (2), penyisihan penghapusan aset untuk aset produktif berupa cadangan umum dan cadangan khusus, sementara untuk aset non produktif hanya berupa cadangan khusus. Berdasarkan Peraturan Bank Indonesia Nomor 14/ 15/ PBI/ 2012 tentang penilaian kualitas aset bank umum pasal 42 ayat (1), besarnya cadangan umum ditetapkan paling kurang sebesar $1 \%$ dari aset produktif yang memiliki kualitas lancar.

Berdasarkan Peraturan Bank Indonesia Nomor 14/ 15/ PBI/ 2012 tentang penilaian kualitas aset bank umum pasal 42 ayat (3), besarnya cadangan khusus ditetapkan minimal sebesar: a. 5\% dari aset dengan kualitas dalam perhatian khusus setelah dikurangi nilai agunan, b. 15\% dari aset dengan kualitas kurang lancar setelah dikurangi nilai agunan, c. $50 \%$ dari aset dengan kualitas diragukan setelah dikurangi nilai agunan, dan d. $100 \%$ dari aset dengan kualitas macet setelah dikurangi nilai agunan. Berdasarkan Peraturan Bank Indonesia Nomor 14/ 15/ PBI/ 2012 tentang penilaian kualitas aset bank umum pasal 43:

"Agunan yang dapat diperhitungkan sebagai pengurang dalam perhitungan penyisihan penghapusan aset adalah: a. Surat berharga dan saham yang aktif diperdagangkan di Bursa Efek di Indonesia atau memiliki peringkat investasi dan diikat secara gadai, b. Tanah, gedung, dan rumah tinggal yang diikat dengan hak tanggungan, c. Mesin yang merupakan satu kesatuan dengan tanah yang diikat dengan hak tanggungan, d. Pesawat udara atau kapal laut dengan ukuran di atas 20 meter kubik yang diikat dengan hipotek, e. Kendaraan bermotor dan persediaan yang diikat secara fidusia, dan/ atau f. Resi gudang yang diikat dengan hak jaminan atas resi gudang."

Menurut Tobing dan Anggorowati (2009: 51) bank Indonesia memang sudah menentukan besarnya penyisihan dalam batasan persentase tertentu, namun pihak manajemen bank masih diberikan kebebasan untuk menentukan kualitas aset berdasarkan ketentuan yang diatur dalam peraturan bank Indonesia dan membentuk cadangan loan loss provisions melebihi cadangan yang wajib dibentuk. Dengan kata lain sangat memungkinkan loan loss provisions dijadikan obyek oleh perusahaan dalam melakukan perataan laba atau terjadi discretionary loan loss provisions di dalam perusahaan dalam upaya meratakan laba perusahaan. 
Earnings Before Tax And Provisions. Menurut Kanagaretnam, et al. (2003: 66) premanaged earnings adalah "Earnings before tax and provisions for loan losses deflated by beginning total assets." Perusahaan menilai bahwa kinerja perusahaan bagus jika premanaged earnings berada di atas median pre-managed earnings perusahaan lainnya. Sebaliknya, perusahaan menilai bahwa kinerja perusahaan tidak bagus jika pre-managed earnings berada di bawah median pre-managed earnings perusahaan lainnya.

Penelitian Kanagaretnam, et al. (2003: 77), Perez, et al. (2006: 23), Dong, et al. (2012: 177), Syahfandi dan Mutmainah (2012: 23), serta Ikhwana dan Rokhaniyah (2015) menunjukkan bahwa earnings before tax and provisions memiliki pengaruh positif terhadap discretionary loan loss provisions. Perusahaan yang memiliki kinerja bagus di periode ini dan memprediksi kinerja yang tidak bagus di masa yang akan datang (goodpoor) akan menyimpan laba tahun ini untuk digunakan di masa yang akan datang dengan cara mengurangi laba melalui peningkatan discretionary loan loss provisions. Sebaliknya, perusahaan yang memiliki kinerja yang tidak bagus di periode ini dan memprediksi kinerja yang bagus di masa yang akan datang (poor-good) akan meningkatkan laba tahun ini dengan cara meminjam laba di masa yang akan datang melalui penurunan discretionary loan loss provisions.

Penelitian Kwak, et al. (2009: 21) menunjukkan bahwa earnings before tax and provisions memiliki pengaruh negatif terhadap discretionary loan loss provisions. Hal ini disebabkan karena perusahaan yang mengalami keuntungan pada masa resesi lebih optimis bahwa keadaan ekonomi di masa yang akan datang akan membaik dan perusahaan tersebut memilih untuk melaporkan discretionary loan loss provisions yang lebih rendah guna memaksimalkan laba. Perusahaan memaksimalkan laba untuk menunjukkan kekuatan finansial perusahaan kepada investor dan pemerintah.

Kualitas Pengungkapan Sukarela. Menurut Suwardjono (2007) dalam Zuliyanto (2013: 227) pengungkapan bertujuan untuk menyajikan informasi yang dipandang perlu untuk mencapai tujuan pelaporan keuangan dan untuk melayani berbagai pihak yang mempunyai kepentingan berbeda-beda. Menurut Ginting (2013: 176-177) salah satu bentuk kualitas pengungkapan adalah keluasan pengungkapan. Terdapat tiga konsep mengenai luas pengungkapan laporan keuangan yaitu adequate, fair, dan full disclosure. Adequate disclosure adalah pengungkapan minimum yang disyaratkan oleh peraturan yang berlaku, dimana pada tingkat pengungkapan ini investor dapat menginterpretasikan angka-angka dalam laporan keuangan dengan benar. Fair disclosure adalah pengungkapan melebihi yang disyaratkan oleh peraturan yang berlaku dengan tujuan menyediakan informasi yang layak terhadap investor potensial. Full disclosure adalah pengungkapan atas semua informasi yang relevan.

Menurut Ginting (2013: 177) jenis pengungkapan laporan keuangan dikelompokkan menjadi pengungkapan wajib dan pengungkapan sukarela. Pengungkapan wajib merupakan pengungkapan mengenai informasi yang harus diungkapkan oleh perusahaan dalam laporan keuangan yang telah diatur. Di Indonesia pengungkapan ini diatur dalam Keputusan Ketua Badan Pengawas Pasar Modal dan Lembaga Keuangan Nomor: KEP347/ BL/ 2012 tentang penyajian dan pengungkapan laporan keuangan emiten atau perusahaan publik dan Keputusan Ketua Badan Pengawas Pasar Modal dan Lembaga Keuangan Nomor: KEP-431/ BL/ 2012 tentang penyampaian laporan tahunan emiten atau perusahaan publik. Pengungkapan sukarela merupakan pengungkapan informasi melebihi persyaratan minimum dari peraturan yang berlaku. 
Menurut Wild (2004) dalam Zuliyanto (2013: 228) ada beberapa alasan perusahaan melakukan pengungkapan sukarela. Alasan pertama adalah tuntutan hukum. Perusahaan memiliki kemungkinan menghadapi tuntutan yang lebih kecil dari investor apabila perusahaan dengan sukarela mengungkapkan informasi penting, terutama yang bersifat merugikan. Alasan kedua adalah penyesuaian prediksi. Perusahaan memiliki insentif untuk melaporkan informasi saat mereka percaya bahwa prediksi pasar sangat berbeda dengan prediksi mereka. Alasan ketiga adalah mengungkapkan berita baik mengenai perusahaan guna meningkatkan harga saham perusahaan. Menurut Ginting (2013: 177) perusahaan melakukan pengungkapan sukarela karena dipandang relevan dengan kebutuhan pemakai laporan keuangan. Pengungkapan sukarela secara lebih luas juga merupakan cara manajer untuk meningkatkan kredibilitas perusahaan.

Penelitian Sanjaya dan Young (2012: 373) menunjukkan bahwa kualitas pengungkapan sukarela memiliki pengaruh negatif terhadap discretionary loan loss provisions. Hal ini disebabkan karena ada pengawasan ketat oleh bank Indonesia atas operasional bisnis perusahaan sehingga perusahaan akan menyiapkan pengungkapan yang luas ke publik agar publik mengetahui bahwa perusahaan tidak memanipulasi laporan keuangan. Semakin banyak luas pengungkapan yang dilakukan oleh perusahaan maka akan mencegah dan menurunkan kesempatan manajemen untuk melakukan kesalahan dengan memanipulasi discretionary loan loss provisions.

Kebutuhan Pendanaan Eksternal. Brealey, et al. (2011: 490) mengemukakan peckingorder theory dalam pendanaan perusahaan: (1) Perusahaan lebih menyukai pendanaan internal, (2) Perusahaan menyesuaikan target dividend payout ratio dengan kesempatan investasi, (3) Apabila arus kas masuk perusahaan lebih besar daripada pengeluaran modal, maka perusahaan akan melunasi hutangnya atau melakukan investasi pada sekuritas, dan sebaliknya, apabila arus kas masuk perusahaan lebih kecil daripada pengeluaran modal, maka perusahaan akan menjual sekuritasnya, dan (4) Apabila perusahaan membutuhkan pendanaan eksternal, perusahaan pertama-tama akan memilih alternatif pendanaan yang lebih aman dengan urutan hutang, hybrid securities seperti konversi obligasi, dan ekuitas. Perusahaan yang tingkat profitabilitasnya tidak terlalu tinggi akan menerbitkan hutang karena mereka tidak memiliki sumber pendanaan internal yang cukup untuk membiayai operasi mereka. Berdasarkan pecking-order theory, hutang merupakan alternatif pertama dalam pendanaan eksternal.

Penelitian Kanagaretnam, et al. (2003: 75) pada kondisi good-poor dan Kwak, et al. (2009: 19) menunjukkan bahwa kebutuhan pendanaan eksternal memiliki pengaruh positif terhadap discretionary loan loss provisions. Perusahaan yang membutuhkan pendanaan eksternal akan melakukan peningkatan discretionary loan loss provisions guna mengurangi laba tahun ini dan menyimpan laba tahun ini untuk digunakan di masa yang akan datang. Pola ini dilakukan agar dapat mengurangi fluktuasi laba yang terlalu besar karena pada umumnya pihak ketiga lebih menyukai laba yang relatif stabil.

Alternatif Lain Untuk Manajemen Laba. Menurut Tobing dan Anggorowati (2009: 60) alternatif lain untuk manajemen laba adalah realisasi keuntungan atau kerugian atas sekuritas held for sale. Penelitian Kwak, et al. (2009: 21) menunjukkan bahwa alternatif lain untuk manajemen laba memiliki pengaruh positif terhadap discretionary loan loss provisions. Penelitian Tobing dan Anggorowati (2009: 59) pada kondisi poor-good menunjukkan bahwa alternatif lain untuk manajemen laba memiliki pengaruh negatif 
terhadap discretionary loan loss provisions. Hal ini menunjukkan bahwa perusahaan menggunakan realisasi keuntungan atau kerugian atas sekuritas held for sale tidak hanya untuk menaikkan laba tapi juga menurunkan laba dengan cara memanipulasi discretionary loan loss provisions.

Ukuran Perusahaan. Menurut Zuliyanto (2013: 230) ukuran perusahaan dapat dinyatakan dalam total aset, penjualan, dan kapitalisasi pasar. Ketiga variabel tersebut digunakan untuk menentukan ukuran perusahaan karena dapat mewakili seberapa besar perusahaan tersebut. Semakin besar aset yang dimiliki maka semakin banyak modal yang ditanam sehingga perusahaan lebih besar. Penjualan yang lebih tinggi mengakibatkan perputaran uang yang lebih tinggi sehingga perusahaan lebih besar. Semakin besar kapitalisasi pasar maka perusahaan tersebut semakin besar dan dikenal masyarakat. Di antara ketiga variabel tersebut, nilai aset relatif lebih stabil dibandingkan dengan nilai penjualan dan nilai kapitalisasi pasar sehingga nilai aset lebih banyak digunakan untuk mengukur ukuran perusahaan.

Penelitian Kanagaretnam, et al. (2003: 78) pada kondisi poor-good, Tobing dan Anggorowati (2009: 60) pada kondisi poor-good, Taktak, et al. (2010: 16), serta Syahfandi dan Mutmainah (2012: 24) menunjukkan bahwa ukuran perusahaan memiliki pengaruh positif terhadap discretionary loan loss provisions. Perusahaan yang lebih besar akan lebih mendapatkan perhatian dari masyarakat sehingga mendorong perusahaan melakukan peningkatan discretionary loan loss provisions guna mengurangi laba tahun ini dan menyimpan laba tahun ini untuk digunakan di masa yang akan datang. Tujuannya adalah agar dapat mengurangi fluktuasi laba yang terlalu besar karena pada umumnya pihak ketiga lebih menyukai laba yang relatif stabil.

Penelitian Terdahulu dan Pengembangan Hipotesis. Kanagaretnam, et al. (2003) melakukan penelitian terhadap 4.166 data kuartalan bank di US selama tahun 1987-2000 mengenai motivasi para manajer bank melakukan perataan laba melalui discretionary loan loss provisions. Ketika bank memiliki kinerja yang bagus di periode ini dan memprediksi kinerja yang tidak bagus di masa yang akan datang (good-poor), maka manajer cenderung akan menyimpan laba tahun ini untuk digunakan di masa yang akan datang dengan cara mengurangi laba melalui peningkatan discretionary loan loss provisions. Ketika bank memiliki kinerja yang tidak bagus di periode ini dan memprediksi kinerja yang bagus di masa yang akan datang (poor-good), maka manajer cenderung akan meningkatkan laba tahun ini dengan cara meminjam laba di masa yang akan datang melalui penurunan discretionary loan loss provisions. Kinerja perusahaan diukur dengan pre-managed earnings yaitu earnings before tax and provisions for loan losses dibagi dengan total aset awal.

Hasil penelitian Kanagaretnam, et al. (2003) juga menunjukkan bahwa pada kondisi good-poor, kebutuhan pendanaan eksternal dan perubahan loan memiliki pengaruh terhadap discretionary loan loss provisions sedangkan alternatif lain untuk manajemen laba, pemenuhan kewajiban modal minimum, non performing loan, perubahan non performing loan, dan ukuran perusahaan tidak memiliki pengaruh terhadap discretionary loan loss provisions. Pada kondisi poor-good, kebutuhan pendanaan eksternal, non performing loan, perubahan non performing loan, dan perubahan loan memiliki pengaruh terhadap discretionary loan loss provisions sedangkan alternatif lain untuk manajemen 
laba, pemenuhan kewajiban modal minimum, dan ukuran perusahaan tidak memiliki pengaruh terhadap discretionary loan loss provisions.

Perez, et al. (2006) melakukan penelitian terhadap 142 bank di Spanish selama tahun 1986-2002. Hasil penelitian menunjukkan bahwa non performing loan, ratio of total loans over total assets, dan earnings before tax and provisions memiliki pengaruh positif terhadap discretionary loan loss provisions. Gross domestic product growth memiliki pengaruh negatif terhadap discretionary loan loss provisions. General index of the Madrid Stock Exchange, total capital ratio, dan ukuran perusahaan tidak memiliki pengaruh terhadap discretionary loan loss provisions.

Kwak, et al. (2009) melakukan penelitian terhadap 252 data tahunan bank di Tokyo Stock Exchange selama tahun 1996-1999. Hasil penelitian menunjukkan bahwa kebutuhan pendanaan eksternal, alternatif lain untuk manajemen laba, dan beban pajak periode sebelumnya memiliki pengaruh positif terhadap discretionary loan loss provisions. Equity capital ratio dan earnings before tax and provisions memiliki pengaruh negatif terhadap discretionary loan loss provisions. Jenis bank, keanggotaan keiretsu, dan ukuran perusahaan tidak memiliki pengaruh terhadap discretionary loan loss provisions.

Tobing dan Anggorowati (2009) melakukan penelitian terhadap 22 perusahaan perbankan nasional yang terdaftar di Bursa Efek Indonesia selama tahun 2005-2007. Hasil penelitian menunjukkan perusahaan yang memiliki kinerja bagus di periode ini dan memprediksi kinerja yang tidak bagus di masa yang akan datang (good-poor) akan melakukan tindakan perataan laba melalui peningkatan discretionary loan loss provisions sebagai upaya untuk menyimpan laba tahun ini untuk digunakan di masa yang akan datang. Ketika perusahaan memiliki kinerja yang tidak bagus di periode ini dan memprediksi kinerja yang bagus di masa yang akan datang (poor-good), maka perusahaan cenderung akan meningkatkan laba tahun ini dengan cara meminjam laba di masa yang akan datang melalui penurunan discretionary loan loss provisions.

Hasil penelitian Tobing dan Anggorowati (2009) juga menunjukkan pada kondisi good-poor, alternatif lain untuk manajemen laba, kebutuhan pendanaan eksternal, non performing loan, perubahan non performing loan, perubahan loan, dan ukuran perusahaan tidak memiliki pengaruh terhadap discretionary loan loss provisions. Pada kondisi poorgood, alternatif lain untuk manajemen laba, non performing loan, dan ukuran perusahaan memiliki pengaruh terhadap discretionary loan loss provision sedangkan kebutuhan pendanaan eksternal, perubahan non performing loan, dan perubahan loan tidak memiliki pengaruh terhadap discretionary loan loss provisions.

Taktak, et al. (2010) melakukan penelitian terhadap 66 perusahaan perbankan dari 19 negara selama tahun 2001-2006. Hasil penelitian menunjukkan bahwa ratio of total loans, non performing loan, capital adequacy ratio, dan ukuran perusahaan memiliki pengaruh terhadap discretionary loan loss provisions sedangkan earnings before tax and provisions dan rate of growth gross domestic product tidak memiliki pengaruh terhadap discretionary loan loss provisions.

Dong, et al. (2012) melakukan penelitian terhadap 14 bank komersial domestik di China selama tahun 2001-2009. Hasil penelitian menunjukkan bahwa earnings before tax and provisions memiliki pengaruh positif terhadap discretionary loan loss provisions sedangkan capital adequacy ratio memiliki pengaruh negatif terhadap discretionary loan loss provisions. 
Sanjaya dan Young (2012) melakukan penelitian terhadap 29 perusahaan perbankan yang terdaftar di Bursa Efek Indonesia selama tahun 2005-2009. Hasil penelitian menunjukkan bahwa kualitas pengungkapan sukarela memiliki pengaruh negatif terhadap discretionary loan loss provisions.

Syahfandi dan Mutmainah (2012) melakukan penelitian terhadap 76 perusahaan perbankan syariah di Indonesia selama tahun 2009-2011. Hasil penelitian menunjukkan bahwa jumlah pembiayaan, risiko pembiayaan, earnings before tax and provisions, dan ukuran perusahaan memiliki pengaruh terhadap discretionary loan loss provisions sedangkan kecukupan modal dan umur perusahaan tidak memiliki pengaruh terhadap discretionary loan loss provisions.

Ginting (2013) melakukan penelitian terhadap 159 perusahaan manufaktur yang terdaftar di Bursa Efek Indonesia selama tahun 2001-2005. Hasil penelitian menunjukkan bahwa kualitas pengungkapan sukarela tidak memiliki pengaruh terhadap discretionary loan loss provisions. Berdasarkan uraian di atas maka perumusan hipotesis adalah sebagai berikut:

$\mathrm{Ha}_{1}$ : Earnings before tax and provisions memiliki pengaruh terhadap discretionary loan loss provisions.

$\mathrm{Ha}_{2}$ : Kualitas pengungkapan sukarela memiliki pengaruh terhadap discretionary loan loss provisions.

Ha3: Kebutuhan pendanaan eksternal memiliki pengaruh terhadap discretionary loan loss provisions.

Ha4: Alternatif lain untuk manajemen laba memiliki pengaruh terhadap discretionary loan loss provisions.

Ha5: Ukuran perusahaan memiliki pengaruh terhadap discretionary loan loss provisions. Hubungan antara variabel independen dan variabel dependen dapat digambarkan melalui model penelitian yang dapat dilihat pada gambar 1 .

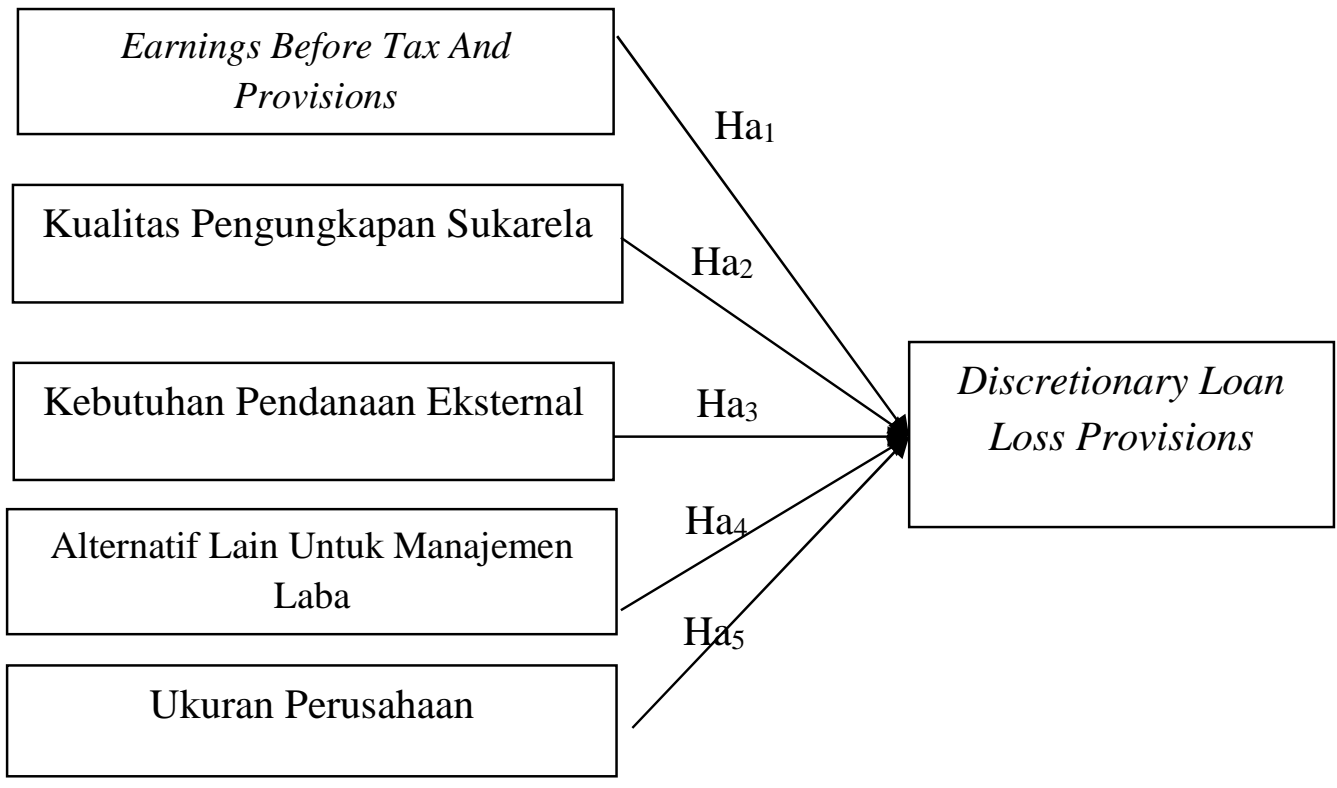

Gambar 1. Model Penelitian

Sumber: Diolah Penulis 


\section{METODE}

Populasi dan Metode Pengambilan Sampel. Populasi dalam penelitian ini adalah seluruh perusahaan perbankan yang terdaftar di Bursa Efek Indonesia selama tahun 20112013. Pemilihan sampel menggunakan metode purposive sampling, artinya populasi yang dijadikan sampel merupakan populasi yang memenuhi kriteria yang telah ditentukan. Perusahaan yang akan dijadikan sampel penelitian adalah perusahaan yang memiliki kriteria sebagai berikut: (1) Perusahaan mempublikasikan laporan keuangan yang berakhir per tanggal 31 Desember, (2) Perusahaan menyajikan laporan keuangan dalam mata uang Rupiah, (3) Perusahaan memiliki informasi mengenai pengungkapan sukarela, (4) Perusahaan tidak melakukan penggabungan usaha baik merger ataupun konsolidasi, dan e. Perusahaan tidak mengalami kerugian.

Operasionalisasi Variabel Penelitian. Variabel terikat dalam penelitian ini adalah discretionary loan loss provisions sedangkan variabel bebas dalam penelitian ini terdiri dari earnings before tax and provisions, kualitas pengungkapan sukarela, kebutuhan pendanaan eksternal, alternatif lain untuk manajemen laba, dan ukuran perusahaan.

Discretionary Loan Loss Provisions. Menurut Dong, et al. (2012: 172) loan loss provisions terdiri dari dua komponen yaitu non discretionary loan loss provisions dan discretionary loan loss provisions. Menurut Kanagaretnam, et al. (2003: 65) komponen non discretionary merupakan penurunan aset keuangan yang terjadi secara alami sedangkan komponen discretionary merupakan penurunan aset keuangan akibat kebijakan manajemen.

Menurut Kanagaretnam, et al. (2003: 65) komponen discretionary merupakan bukti langsung manajemen melakukan perataan laba. Menurut Kanagaretnam, et al. (2003: 6970) komponen non discretionary dalam menentukan loan loss provisions adalah saldo awal kredit bermasalah (NPLit-1), perubahan saldo kredit bermasalah (CHNPL $\mathrm{C}_{\mathrm{it}}$ ), dan perubahan saldo kredit $\left(\mathrm{CHLOAN}_{\mathrm{it}}\right)$. NPLit-1, CHNPL $\mathrm{it}$, dan $\mathrm{CHLOAN}_{\mathrm{it}}$ memiliki pengaruh positif terhadap komponen non-discretionary pada loan loss provisions. Loan loss provisions yang diberi simbol LLP diperoleh dengan membandingkan beban penyisihan kerugian penurunan nilai aset produktif dengan saldo awal kredit yang diberikan. NPLit-1 diperoleh dengan membandingkan saldo awal kredit bermasalah dengan saldo awal kredit yang diberikan. CHNPL it diperoleh dengan membandingkan perubahan saldo kredit bermasalah dengan saldo awal kredit yang diberikan. CHLOAN $\mathrm{N}_{\text {it }}$ diperoleh dengan membandingkan perubahan saldo kredit dengan saldo awal kredit yang diberikan.

$$
\mathrm{LLP}_{\text {it }}=\mathrm{a}+\mathrm{b}_{1} \mathrm{NPL}_{\mathrm{it}-1}+\mathrm{b}_{2} \mathrm{CHNPL}_{\mathrm{it}}+\mathrm{b}_{3} \mathrm{CHLOAN}_{\mathrm{it}}+\mathrm{e}
$$

Keterangan:

$$
\begin{array}{ll}
\text { LLP }_{\text {it }} & =\frac{\text { Beban penyisihan kerugian penurunan nilai aset produktif }}{\text { Saldo awal kredit yang diberikan }} \\
\mathrm{a} & =\text { Konstanta } \\
\mathrm{b}_{1-3} & =\text { Koefisien regresi } \\
\text { NPLit-1 } & =\frac{\text { Saldo awal kredit bermasalah }}{\text { Saldo awal kredit yang diberikan }}
\end{array}
$$




\begin{tabular}{|c|c|c|}
\hline \multirow{2}{*}{ CHNPLit $_{\text {it }}$} & \multirow[t]{2}{*}{$=$} & $\underline{\text { Perubahan saldo kredit bermasalah }}$ \\
\hline & & Saldo awal kredit yang diberikan \\
\hline \multirow{2}{*}{ CHLOAN $_{\text {it }}$} & $=$ & $\underline{\text { Perubahan saldo kredit }}$ \\
\hline & & Saldo awal kredit yang diberikan \\
\hline & & Residual term \\
\hline
\end{tabular}

Nilai konstanta dan koefisien regresi tiap variabel yang diperoleh kemudian digunakan untuk menentukan nilai non discretionary loan loss provisions. Setelah itu, untuk mendapatkan nilai discretionary loan loss provisions adalah dengan cara mencari selisih antara loan loss provisions dengan non discretionary loan loss provisions. Skala pengukuran yang digunakan adalah skala rasio.

Earnings Before Tax And Provisions. Menurut Dong, et al. (2012: 172) earnings before tax and provisions adalah perbandingan laba sebelum pajak penghasilan dan beban penyisihan kerugian penurunan nilai aset produktif dengan total aset. Earnings before tax and provisions diberi simbol EBTP dan skala pengukuran yang digunakan adalah skala rasio. Sesuai penelitian Dong, et al. (2012: 172) EBTP dihitung dengan rumus:

EBTP $=\underline{\text { Laba sebelum pajak dan beban penyisihan kerugian penurunan nilai aset produktif }}$ Total aset

Kualitas Pengungkapan Sukarela. Menurut Ginting (2013: 177) kualitas pengungkapan sukarela adalah perbandingan jumlah elemen informasi yang dipenuhi dengan jumlah elemen informasi yang mungkin dipenuhi. Untuk mengukur kualitas pengungkapan sukarela digunakan indeks pengungkapan dengan mengacu pada penelitian Haji dan Ghazali (2013: 42). Data kualitas pengungkapan sukarela diperoleh dengan memberikan skor 1 untuk setiap pengungkapan yang memenuhi indeks pengungkapan dan dijumlahkan lalu dibagi dengan jumlah elemen informasi yang mungkin dipenuhi. Menurut Ginting (2013: 177) semakin tinggi angka indeks pengungkapan maka semakin tinggi kualitas pengungkapan sukarela. Kualitas pengungkapan sukarela diberi simbol VOLDISC dan skala pengukuran yang digunakan adalah skala rasio. Sesuai penelitian Ginting (2013: 177) VOLDISC dihitung dengan rumus:

VOLDISC $=\frac{\text { Jumlah elemen informasi yang dipenuhi }}{\text { Jumlah elemen informasi yang mungkin dipenuhi }}$

Kebutuhan Pendanaan Eksternal. Menurut Kanagaretnam, et al. (2003: 70) kebutuhan pendanaan eksternal adalah perbandingan total kredit yang diberikan ke pihak ketiga dengan dana pihak ketiga. Menurut Cocheo (1997) dan Petersen (1999) dalam Kanagaretnam, et al. (2003: 68) rasio loan to deposit sering digunakan untuk menentukan kebutuhan pendanaan eksternal. Ginting dan Haryanto (2016: 3) menyebutkan rasio loan to deposit menunjukkan kemampuan bank dalam membayar kembali penarikan dana yang dilakukan oleh deposan dengan mengandalkan kredit yang diberikan sebagai sumber likuiditasnya. Rasio loan to deposit merupakan perbandingan kredit yang disalurkan oleh bank terhadap modal yang tersedia. 
Secara sederhana, semakin tinggi nilai rasio loan to deposit menunjukkan semakin tinggi pula nilai kredit yang disalurkan oleh bank. Semakin tinggi nilai kredit mengindikasikan semakin tinggi pula risiko kredit yang mungkin terjadi. Kebutuhan pendanaan eksternal diberi simbol LDR dan skala pengukuran yang digunakan adalah skala rasio. Sesuai penelitian Kanagaretnam, et al. (2003: 70) LDR dihitung dengan rumus:

\section{$\mathrm{LDR}=\underline{\text { Total kredit yang diberikan ke pihak ketiga }}$ \\ Dana pihak ketiga}

Berdasarkan Surat Edaran Bank Indonesia Nomor 15/ 41/ DKMP perihal perhitungan giro wajib minimum sekunder dan giro wajib minimum berdasarkan loan to deposit ratio dalam Rupiah, loan to deposit ratio adalah rasio kredit yang diberikan kepada pihak ketiga dalam Rupiah dan valuta asing, tidak termasuk kredit kepada bank lain. Dana pihak ketiga adalah giro, tabungan, dan deposito dalam Rupiah dan valuta asing, tidak termasuk dana antar bank.

Alternatif Lain Untuk Manajemen Laba. Menurut Kanagaretnam, et al. (2003: 70) alternatif lain untuk manajemen laba adalah perbandingan keuntungan atau kerugian atas sekuritas held for sale dengan total aset. Menurut Barth, et al. (1990), Warfield dan Linsmeier (1992), serta Beatty dan Haris (1999) dalam Kanagaretnam, et al. (2003: 68) manajer bank menggunakan realisasi keuntungan atau kerugian atas sekuritas held for sale untuk menentukan alternatif lain untuk manajemen laba. Alternatif lain untuk manajemen laba diberi simbol RGLASS dan skala pengukuran yang digunakan adalah skala rasio. Sesuai penelitian Kanagaretnam, et al. (2003: 70) RGLASS dihitung dengan rumus:

RGLASS $=\underline{\text { Keuntungan atau kerugian atas sekuritas held for sale }}$

Total aset

Ukuran Perusahaan. Menurut Kwak, et al. (2009: 11) ukuran perusahaan adalah natural logarithm dari total aset. Menurut Zuliyanto (2013: 230) ukuran perusahaan dapat dinyatakan dalam total aset. Ukuran perusahaan diberi simbol LASSET dan skala pengukuran yang digunakan adalah skala rasio. Sesuai penelitian Kwak, et al. (2009: 11) LASSET dihitung dengan rumus:

LASSET $=$ Natural logarithm dari total aset

Teknik Pengumpulan Data. Obyek penelitian ini adalah pengaruh earnings before tax and provisions, kualitas pengungkapan sukarela, kebutuhan pendanaan eksternal, alternatif lain untuk manajemen laba, dan ukuran perusahaan terhadap discretionary loan loss provisions pada perusahaan perbankan yang terdaftar di Bursa Efek Indonesia selama tahun 2011-2013. Data yang digunakan dalam penelitian ini adalah data sekunder yang berasal dari Bursa Efek Indonesia berupa laporan keuangan dan laporan tahunan emiten selama tahun 2011-2013 yang diperoleh dari website www.idx.co.id. Data yang diperoleh kemudian diolah dan diuji dengan menggunakan bantuan program software Statistical Product and Service Solution (SPSS) for Windows versi 20.

Teknik Pengolahan Data. Analisis yang dilakukan dalam penelitian ini adalah analisis yang bersifat kuantitatif, dengan menggunakan analisis regresi Ordinary Least Square. Sebelum dilakukan semua pengujian, langkah awal adalah melakukan beberapa pengujian 
asumsi klasik terhadap data yang dikumpulkan, karena model regresi Ordinary Least Square mengandung beberapa asumsi klasik yang harus dipenuhi.

Model regresi dalam penelitian ini adalah DLLP $=a+b_{1}$ EBTP $+b_{2}$ VOLDISC + $\mathrm{b}_{3}$ LDR $+\mathrm{b}_{4}$ RGLASS $+\mathrm{b}_{5}$ LASSET $+\mathrm{e}$, dimana DLLP $=$ Discretionary loan loss provisions $; \mathrm{a}=$ Konstanta; $\mathrm{b}_{1-5} \quad=$ Koefisien regresi; $\mathrm{EBTP}=$ Earnings before tax and provisions; VOLDISC $=$ Kualitas pengungkapan sukarela; LDR $=$ Kebutuhan pendanaan eksternal; RGLASS = Alternatif lain untuk manajemen laba; LASSET = Ukuran perusahaan; dan e = Residual term. Setelah semua uji asumsi klasik yaitu normalitas, heteroskedastisitas, multikolinieritas, dan autokorelasi terpenuhi, langkah berikutnya adalah menguji hipotesis penelitian apakah variabel independen dapat digunakan untuk memprediksi variabel dependen. Untuk itu dilakukan uji statistik dengan menggunakan uji F (uji secara bersama-sama) maupun uji t (uji secara parsial). Penelitian ini menggunakan tingkat kesalahan sebesar 5\%.

Pemilihan Sampel. Populasi dalam penelitian ini adalah seluruh perusahaan perbankan yang terdaftar di Bursa Efek Indonesia selama tahun 2011-2013. Perusahaan yang akan dijadikan sampel penelitian adalah perusahaan yang memiliki kriteria sebagai berikut: a. Perusahaan mempublikasikan laporan keuangan yang berakhir per tanggal 31 Desember, b. Perusahaan menyajikan laporan keuangan dalam mata uang Rupiah, c. Perusahaan memiliki informasi mengenai pengungkapan sukarela, d. Perusahaan tidak melakukan penggabungan usaha baik merger ataupun konsolidasi, dan e. Perusahaan tidak mengalami kerugian. Berdasarkan kriteria tersebut diperoleh 26 perusahaan perbankan sehingga sampel dalam penelitian ini adalah sebanyak 78 data.

\section{HASIL DAN PEMBAHASAN}

Statistik Deskriptif. Statistik deskriptif digunakan untuk memberikan gambaran nilai minimum, nilai maksimum, nilai rata-rata, dan standar deviasi dari variabel yang diteliti yaitu discretionary loan loss provisions, earnings before tax and provisions, kualitas pengungkapan sukarela, kebutuhan pendanaan eksternal, alternatif lain untuk manajemen laba, dan ukuran perusahaan.

Tabel 1. Statistik Deskriptif

\begin{tabular}{lcrrrr}
\hline & N & \multicolumn{1}{c}{ Minimum } & Maximum & \multicolumn{1}{c}{ Mean } & \multicolumn{1}{c}{ Std. Deviation } \\
\hline DLLP & 78 & $-0,0218$ & 0,0422 & $-0,000206$ & 0,0095684 \\
EBTP & 78 & 0,0083 & 0,0522 & 0,024678 & 0,0118073 \\
VOLDISC & 78 & 0,2917 & 0,6875 & 0,487179 & 0,0996720 \\
LDR & 78 & 0,4397 & 1,9589 & 0,900372 & 0,2427079 \\
RGLASS & 78 & $-0,0013$ & 0,0085 & 0,001314 & 0,0022563 \\
LASSET & 78 & 21,4558 & 27,3205 & 24,446554 & 1,6476215 \\
Valid N (listwise) & 78 & & & & \\
\hline
\end{tabular}

Sumber: Hasil Pengolahan SPSS

Tabel 1. menunjukkan bahwa discretionary loan loss provisions (DLLP) memiliki nilai minimum sebesar -0,0218 dan nilai maksimum sebesar 0,0422. Discretionary loan loss provisions memiliki nilai rata-rata sebesar $-0,000206$ dan nilai standar deviasi sebesar 0,0095684. Earnings before tax and provisions (EBTP) memiliki nilai minimum sebesar 
0,0083 dan nilai maksimum sebesar 0,0522. Earnings before tax and provisions memiliki nilai rata-rata sebesar 0,024678 dan nilai standar deviasi sebesar 0,0118073.

Kualitas pengungkapan sukarela (VOLDISC) memiliki nilai minimum sebesar 0,2917 dan nilai maksimum sebesar 0,6875 . Kualitas pengungkapan sukarela memiliki nilai rata-rata sebesar 0,487179 dan nilai standar deviasi sebesar 0,0996720. Kebutuhan pendanaan eksternal (LDR) memiliki nilai minimum sebesar 0,4397 dan nilai maksimum sebesar 1,9589. Kebutuhan pendanaan eksternal memiliki nilai rata-rata sebesar 0,900372 dan nilai standar deviasi sebesar 0,2427079.

Alternatif lain untuk manajemen laba (RGLASS) memiliki nilai minimum sebesar 0,0013 dan nilai maksimum sebesar 0,0085. Alternatif lain untuk manajemen laba memiliki nilai rata-rata sebesar 0,001314 dan nilai standar deviasi sebesar 0,0022563. Ukuran perusahaan (LASSET) memiliki nilai minimum sebesar 21,4558 dan nilai maksimum sebesar 27,3205. Ukuran perusahaan memiliki nilai rata-rata sebesar 24,446554 dan nilai standar deviasi sebesar 1,6476215.

Hasil Uji Kualitas Data. Penelitian ini menggunakan uji normalitas dalam menguji kualitas data. Hasil pengujian normalitas dengan menggunakan One-Sample KolmogorovSmirnov Test adalah sebagai berikut:

Tabel 2. Hasil Uji Normalitas

\begin{tabular}{lcc}
\hline Keterangan & $\mathrm{N}$ & Asymp. Sig (2-tailed) \\
\hline Unstandardized Residual & 78 & 0,636 \\
\hline Sumber: Hasil Pengolahan SPSS &
\end{tabular}

Tabel 2. menunjukkan nilai asymp. sig (2-tailed) sebesar 0,636 dimana nilai ini lebih besar dari 0,05 sehingga dapat disimpulkan bahwa residual data berdistribusi normal.

Hasil Uji Asumsi Klasik. Uji Heteroskedastisitas. Hasil pengujian heteroskedastisitas dengan menggunakan uji Glejser adalah sebagai berikut:

Tabel 3. Hasil Uji Heteroskedastisitas

\begin{tabular}{lcc}
\hline \multicolumn{1}{c}{ Variabel } & Sig. & Kesimpulan \\
\hline EBTP & 0,372 & Tidak terjadi heteroskedastisitas \\
VOLDISC & 0,090 & Tidak terjadi heteroskedastisitas \\
LDR & 0,557 & Tidak terjadi heteroskedastisitas \\
RGLASS & 0,723 & Tidak terjadi heteroskedastisitas \\
LASSET & 0,725 & Tidak terjadi heteroskedastisitas \\
\hline
\end{tabular}

Sumber: Hasil Pengolahan SPSS

Tabel 3. menunjukkan bahwa earnings before tax and provisions (EBTP), kualitas pengungkapan sukarela (VOLDISC), kebutuhan pendanaan eksternal (LDR), alternatif lain untuk manajemen laba (RGLASS), dan ukuran perusahaan (LASSET) memiliki nilai signifikansi lebih besar dari 0,05 sehingga dapat disimpulkan bahwa pada model regresi tidak terjadi heteroskedastisitas.

Uji Multikolinieritas. Hasil pengujian multikolinieritas adalah sebagai berikut: 
Tabel 4. Hasil Uji Multikolinieritas

\begin{tabular}{lccc}
\hline \multicolumn{1}{c}{ Variabel } & Tolerance & VIF & Kesimpulan \\
\hline EBTP & 0,655 & 1,527 & Tidak terjadi multikolinieritas \\
VOLDISC & 0,398 & 2,511 & Tidak terjadi multikolinieritas \\
LDR & 0,913 & 1,095 & Tidak terjadi multikolinieritas \\
RGLASS & 0,827 & 1,210 & Tidak terjadi multikolinieritas \\
LASSET & 0,323 & 3,099 & Tidak terjadi multikolinieritas \\
\hline
\end{tabular}

Sumber: Hasil Pengolahan SPSS

Tabel 4. menunjukkan bahwa earnings before tax and provisions (EBTP), kualitas pengungkapan sukarela (VOLDISC), kebutuhan pendanaan eksternal (LDR), alternatif lain untuk manajemen laba (RGLASS), dan ukuran perusahaan (LASSET) memiliki nilai Tolerance di atas 0,1 dan nilai Variance Inflation Factor (VIF) di bawah 10 sehingga dapat disimpulkan bahwa pada model regresi tidak terjadi multikolinieritas.

Uji Autokorelasi. Hasil pengujian autokorelasi dengan menggunakan uji Durbin Watson adalah sebagai berikut:

Tabel 5. Hasil Uji Autokorelasi

\begin{tabular}{cc}
\hline Keterangan & Nilai \\
\hline Durbin Watson & 2,089 \\
dl (tabel D-W) & 1,4991 \\
du (tabel D-W) & 1,7708 \\
4-du & 2,2292 \\
4-dl & 2,5009 \\
\hline
\end{tabular}

Sumber: Hasil Pengolahan SPSS dan Tabel DW

Tabel 5. menunjukkan bahwa nilai Durbin Watson sebesar 2,089. Nilai tersebut berada di antara du dan 4-du sehingga dapat disimpulkan bahwa pada model regresi tidak terjadi autokorelasi.

Model Regresi. Setelah semua uji asumsi klasik terpenuhi, langkah berikutnya adalah melakukan pengujian hipotesis terhadap model regresi. Tujuan analisis ini adalah untuk mengetahui pengaruh earnings before tax and provisions, kualitas pengungkapan sukarela, kebutuhan pendanaan eksternal, alternatif lain untuk manajemen laba, dan ukuran perusahaan terhadap discretionary loan loss provisions pada perusahaan perbankan yang terdaftar di Bursa Efek Indonesia selama tahun 2011-2013.

Tabel 6. Model Regresi

\begin{tabular}{lcccc}
\hline \multicolumn{1}{c}{ Model } & $B$ & Standard Error & $t$ & Sig. \\
\hline Constant & 0,019 & 0,018 & 1,055 & 0,295 \\
EBTP & $-0,511$ & 0,091 & $-5,608$ & 0,000 \\
VOLDISC & 0,005 & 0,014 & 0,375 & 0,709 \\
LDR & 0,001 & 0,004 & 0,223 & 0,824 \\
RGLASS & $-0,333$ & 0,424 & $-0,785$ & 0,435 \\
LASSET & 0,000 & 0,001 & $-0,433$ & 0,666 \\
& & & & \\
\hline
\end{tabular}

Sumber: Hasil Pengolahan SPSS 
Model regresi yang diperoleh adalah: DLLP $=0,019-0,511 \mathrm{EBTP}+0,005$ VOLDISC + 0,001 LDR - 0,333 RGLASS + 0,000 LASSET + e

Tabel 7. Hasil Uji F

\begin{tabular}{lccccc}
\hline \multicolumn{1}{c}{ Model } & Sum of Squares & $d f$ & Mean Square & $F$ & Sig. \\
\hline Regression & 0,003 & 5 & 0,001 & & \\
Residual & 0,004 & 72 & 0,000 & 9,790 & 0,000 \\
Total & 0,007 & 77 & & & \\
\hline
\end{tabular}

Sumber: Hasil Pengolahan SPSS

Tabel 7. menunjukkan nilai signifikansi sebesar 0,000 dimana nilai ini lebih kecil dari 0,05. Ini berarti Ho ditolak dan dapat disimpulkan bahwa paling sedikit terdapat satu variabel independen yang mempengaruhi discretionary loan loss provisions. Dengan demikian uji t (uji secara parsial) untuk menjawab hipotesis penelitian dapat dilakukan untuk mengetahui variabel independen mana saja yang mempengaruhi discretionary loan loss provisions.

Pengujian Hipotesis. Hasil uji t adalah sebagai berikut:

Tabel 8. Hasil Uji t

\begin{tabular}{lccccl}
\hline \multicolumn{1}{c}{ Model } & $B$ & Standard Error & $t$ & Sig. & \multicolumn{1}{c}{ Kesimpulan } \\
\hline EBTP & $-0,511$ & 0,091 & $-5,608$ & 0,000 & Ha1 tidak ditolak \\
VOLDISC & 0,005 & 0,014 & 0,375 & 0,709 & Ha2 ditolak \\
LDR & 0,001 & 0,004 & 0,223 & 0,824 & Ha3 ditolak \\
RGLASS & $-0,333$ & 0,424 & $-0,785$ & 0,435 & Ha4 ditolak \\
LASSET & 0,000 & 0,001 & $-0,433$ & 0,666 & Ha5 ditolak \\
\hline
\end{tabular}

Sumber: Hasil Pengolahan SPSS

Uji Hipotesis Pertama. Hipotesis alternatif pertama $\left(\mathrm{Ha}_{1}\right)$ dalam penelitian ini adalah earnings before tax and provisions memiliki pengaruh terhadap discretionary loan loss provisions. Tabel 8. menunjukkan bahwa nilai signifikansi earnings before tax and provisions adalah sebesar 0,000 dimana nilai ini lebih kecil dari 0,05 sehingga dapat disimpulkan bahwa $\mathrm{Ha}_{1}$ tidak ditolak atau dengan kata lain earnings before tax and provisions memiliki pengaruh terhadap discretionary loan loss provisions. Hasil penelitian ini konsisten dengan penelitian Kanagaretnam, et al. (2003), Perez, et al. (2006), Kwak, et al. (2009), Dong, et al. (2012), serta Syahfandi dan Mutmainah (2012) namun tidak konsisten dengan penelitian Taktak, et al. (2010).

Earnings before tax and provisions memiliki pengaruh negatif terhadap discretionary loan loss provisions. Hasil penelitian ini menunjukkan bahwa ketika laba perusahaan tinggi, perusahaan menurunkan discretionary loan loss provisions guna memaksimalkan laba. Perusahaan memaksimalkan laba dengan tujuan untuk menunjukkan kekuatan finans ial perusahaan kepada pihak eksternal dan juga untuk bonus yang lebih besar.

Uji Hipotesis Kedua. Hipotesis alternatif kedua $\left(\mathrm{Ha}_{2}\right)$ dalam penelitian ini adalah kualitas pengungkapan sukarela memiliki pengaruh terhadap discretionary loan loss 
provisions. Tabel 8. menunjukkan bahwa nilai signifikansi kualitas pengungkapan sukarela adalah sebesar 0,709 dimana nilai ini lebih besar dari 0,05 sehingga dapat disimpulkan bahwa $\mathrm{Ha}_{2}$ ditolak atau dengan kata lain kualitas pengungkapan sukarela tidak memiliki pengaruh terhadap discretionary loan loss provisions. Hasil penelitian ini konsisten dengan penelitian Ginting (2013) namun tidak konsisten dengan penelitian Sanjaya dan Young (2012).

Banyak investor yang berasumsi bahwa perusahaan yang melakukan pengungkapan sukarela secara luas merupakan perusahaan yang transparan dan tidak memiliki masalah yang harus disembunyikan. Oleh karena itu investor tertarik untuk berinvestasi di perusahaan tersebut. Hal ini mendorong perusahaan tidak melakukan discretionary loan loss provisions dan lebih banyak melakukan pengungkapan sukarela yang tidak perlu dan tidak relevan dengan perkembangan manajemen perusahaan. Hal ini dapat menjadi masukan bagi Badan Pengawas Pasar Modal dan lembaga keuangan bahwa masih perlu dibuatkan beberapa kriteria untuk kualitas pengungkapan sukarela karena terkadang segala sesuatu yang diungkapkan dalam pengungkapan sukarela banyak namun seharusnya tidak perlu diungkapkan dan tidak relevan dengan perkembangan manajemen perusahaan.

Uji Hipotesis Ketiga. Hipotesis alternatif ketiga $\left(\mathrm{Ha}_{3}\right)$ dalam penelitian ini adalah kebutuhan pendanaan eksternal memiliki pengaruh terhadap discretionary loan loss provisions. Tabel 8. menunjukkan bahwa nilai signifikansi kebutuhan pendanaan eksternal adalah sebesar 0,824 dimana nilai ini lebih besar dari 0,05 sehingga dapat disimpulkan bahwa $\mathrm{Ha}_{3}$ ditolak atau dengan kata lain kebutuhan pendanaan eksternal tidak memiliki pengaruh terhadap discretionary loan loss provisions. Hasil penelitian ini konsisten dengan penelitian Kanagaretnam, et al. (2003) pada kondisi poor-good serta Tobing dan Anggorowati (2009) namun tidak konsisten dengan penelitian Kanagaretnam, et al. (2003) pada kondisi good-poor dan Kwak, et al. (2009).

Iklim investasi Indonesia yang membaik mendorong investor berlomba-lomba untuk menanamkan modalnya di Indonesia. Hal ini membuat perusahaan-perusahaan di Indonesia tidak terlalu membutuhkan pendanaan eksternal melalui hutang. Manajer perusahaan di Indonesia lebih memusatkan perhatian untuk menarik investor membeli saham perusahaan mereka. Perusahaan juga lebih tertarik memperoleh sumber dana dengan biaya yang lebih murah (seperti melakukan strategi pemasaran yang lebih efektif) tanpa melakukan discretionary loan loss provisions.

Uji Hipotesis Keempat. Hipotesis alternatif keempat (Ha4) dalam penelitian ini adalah alternatif lain untuk manajemen laba memiliki pengaruh terhadap discretionary loan loss provisions. Tabel 8. menunjukkan bahwa nilai signifikansi alternatif lain untuk manajemen laba adalah sebesar 0,435 dimana nilai ini lebih besar dari 0,05 sehingga dapat disimpulkan bahwa $\mathrm{Ha}_{4}$ ditolak atau dengan kata lain alternatif lain untuk manajemen laba tidak memiliki pengaruh terhadap discretionary loan loss provisions. Hasil penelitian ini konsisten dengan penelitian Kanagaretnam, et al. (2003) serta Tobing dan Anggorowati (2009) pada kondisi good-poor namun tidak konsisten dengan penelitian Kwak, et al. (2009) serta Tobing dan Anggorowati (2009) pada kondisi poor-good. Alternatif lain untuk manajemen laba tidak dapat diukur dengan realisasi keuntungan atau kerugian atas sekuritas held for sale karena tidak menjelaskan fenomena terjadinya discretionary loan loss provisions. 
Uji Hipotesis Kelima. Hipotesis alternatif kelima ( $\left.\mathrm{Ha}_{5}\right)$ dalam penelitian ini adalah ukuran perusahaan memiliki pengaruh terhadap discretionary loan loss provisions. Tabel 8. menunjukkan bahwa nilai signifikansi ukuran perusahaan adalah sebesar 0,666 dimana nilai ini lebih besar dari 0,05 sehingga dapat disimpulkan bahwa Has ditolak atau dengan kata lain ukuran perusahaan tidak memiliki pengaruh terhadap discretionary loan loss provisions. Hasil penelitian ini konsisten dengan penelitian Kanagaretnam, et al. (2003) pada kondisi good-poor, Perez, et al. (2006), Kwak, et al. (2009), serta Tobing dan Anggorowati (2009) pada kondisi good-poor namun tidak konsisten dengan penelitian Kanagaretnam, et al. (2003) pada kondisi poor-good, Tobing dan Anggorowati (2009) pada kondisi poor-good, Taktak, et al. (2010), serta Syahfandi dan Mutmainah (2012).

Penggunaan basis akrual dalam penyusunan laporan keuangan mendorong terjadinya manajemen laba. Basis akrual sebenarnya sesuai dengan matching principle yang bertujuan menyajikan laporan keuangan sesuai dengan fakta dan lebih rasional. Prinsip akrual yang banyak menggunakan estimasi ini dimanfaatkan oleh perusahaan untuk mengatur laba. Semua perusahaan, baik besar maupun kecil, melakukan manajemen laba yang bertujuan untuk meratakan laba ataupun memaksimalkan laba sehingga ukuran perusahaan tidak memiliki pengaruh terhadap discretionary loan loss provisions.

\section{PENUTUP}

Earnings before tax and provisions memiliki pengaruh terhadap discretionary loan loss provisions. Hasil penelitian ini konsisten dengan penelitian Kanagaretnam, et al. (2003), Perez, et al. (2006), Kwak, et al. (2009), Dong, et al. (2012), serta Syahfandi dan Mutmainah (2012) namun tidak konsisten dengan penelitian Taktak, et al. (2010) yang menunjukkan bahwa earnings before tax and provisions tidak memiliki pengaruh terhadap discretionary loan loss provisions.

Kualitas pengungkapan sukarela tidak memiliki pengaruh terhadap discretionary loan loss provisions. Hasil penelitian ini konsisten dengan penelitian Ginting (2013) namun tidak konsisten dengan penelitian Sanjaya dan Young (2012) yang menunjukkan bahwa kualitas pengungkapan sukarela memiliki pengaruh terhadap discretionary loan loss provisions.

Kebutuhan pendanaan eksternal tidak memiliki pengaruh terhadap discretionary loan loss provisions. Hasil penelitian ini konsisten dengan penelitian Kanagaretnam, et al. (2003) pada kondisi poor-good serta Tobing dan Anggorowati (2009) namun tidak konsisten dengan penelitian Kanagaretnam, et al. (2003) pada kondisi good-poor dan Kwak, et al. (2009) yang menunjukkan bahwa kebutuhan pendanaan eksternal memiliki pengaruh terhadap discretionary loan loss provisions.

Alternatif lain untuk manajemen laba tidak memiliki pengaruh terhadap discretionary loan loss provisions. Hasil penelitian ini konsisten dengan penelitian Kanagaretnam, et al. (2003) serta Tobing dan Anggorowati (2009) pada kondisi goodpoor namun tidak konsisten dengan penelitian Kwak, et al. (2009) serta Tobing dan Anggorowati (2009) pada kondisi poor-good yang menunjukkan bahwa alternatif lain untuk manajemen laba memiliki pengaruh terhadap discretionary loan loss provisions.

Ukuran perusahaan tidak memiliki pengaruh terhadap discretionary loan loss provisions. Hasil penelitian ini konsisten dengan penelitian Kanagaretnam, et al. (2003) pada kondisi good-poor, Perez, et al. (2006), Kwak, et al. (2009), serta Tobing dan 
Anggorowati (2009) pada kondisi good-poor namun tidak konsisten dengan penelitian Kanagaretnam, et al. (2003) pada kondisi poor-good, Tobing dan Anggorowati (2009) pada kondisi poor-good, Taktak, et al. (2010), serta Syahfandi dan Mutmainah (2012) yang menunjukkan bahwa ukuran perusahaan memiliki pengaruh terhadap discretionary loan loss provisions. Penelitian ini hanya dilakukan pada 26 perusahaan perbankan yang terdaftar di Bursa Efek Indonesia selama tahun 2011-2013. Sebaiknya penelitian selanjutnya memperpanjang periode pengamatan dan menguji faktor-faktor lain yang diperkirakan memiliki pengaruh terhadap discretionary loan loss provisions tapi belum diuji pada penelitian ini seperti beban pajak periode sebelumnya dan non performing loan.

\section{DAFTAR RUJUKAN}

Astuti, Dewi Saptantinah Puji. (2007) "Analisis faktor-faktor yang mempengaruhi motivasi manajemen laba di seputar right issue". Jurnal Ilmiah Akuntansi dan Bisnis. 2 (2) Juli, 1-23

Brealey, Richard A., Stewart C. Myers, and Franklin Allen. (2011) Principles of corporate finance. Tenth Edition. United States of America: McGraw-Hill Irwin

Dong, Xianlei, Jia Liu, and Beibei Hu. (2012) "Research on the relationship of commercial bank's loan loss provision and earning management and capital management". Journal of Service Science and Management. 5, 171-179

Ginting, Jenni Veronika B. R. (2013) "Pengaruh kualitas ungkapan sukarela terhadap earnings management di moderasi biaya research and development pada perusahaan manufaktur yang terdaftar di Bursa Efek Indonesia”. Jurnal Akuntansi dan Manajemen. 24 (3), 175-184

Ginting, Join Syah Putra and Mulyo A. Haryanto. (2016) "Pengaruh capital adequacy ratio, loan to deposit ratio, loan loss provision dan net interest margin terhadap non performing loan (studi kasus pada bank umum konvensional di Indonesia yang terdaftar di BEI pada tahun 2008-2014)". Diponegoro Journal of Management. 5 (1), $1-7$

Haji, Abdifatah Ahmed and Nazli Anum Mohd Ghazali. (2013) "The quality and determinants of voluntary disclosures in annual reports of shari'ah compliant companies in Malaysia". Journal Emerald Humanomics. 29 (1), 24-42

Ikatan Akuntan Indonesia. (2012) Standar akuntansi keuangan per 1 Juni 2012. Jakarta: Salemba Empat

Ikhwana, Fahmi dan Siti Rokhaniyah. (2015) "Income smoothing dan loan loss provision pada perbankan syariah di Indonesia tahun 2012". Jurnal Akuntansi Bisnis dan Ekonomi. 2(1)

Isa, Mohd Yaziz Mohd. (2013) "Loan loss provisioning practices". Journal of Modern Accounting and Auditing. 9 (6), 814-822

Kanagaretnam, Kiridaran, Gerald J. Lobo, and Robert Mathieu. (2003) "Managerial incentives for income smoothing through bank loan loss provisions". Review of Quantitative Finance and Accounting. 20, 63-80

Kwak, Wikil, Ho Young Lee, and Susan W. Eldridge. (2009) "Earnings management by Japanese bank managers using discretionary loan loss provisions". Journal Review of Pacific Basin Financial Markets and Policies. 12 (1), 1-26 
Norden, Lars and Anamaria Stoian. (2013) "Bank earnings management through loan loss provisions: a double-edged sword?". DNB Working Paper. 404, 1-46

Peraturan Bank Indonesia Nomor 14/ 15/ PBI/ 2012 tentang penilaian kualitas aset bank umum

Perez, Daniel, Vicente Salas, and Jesus Saurina. (2006) "Earnings and capital management in alternative loan loss provision regulatory regimes". Banco de Espana. 0614, 1-33

Sanjaya, I Putu Sugiartha. (2011) "The influence of ultimate ownership on earning management: evidence from Indonesia”. Journal of Business Research. 5, 61-69

Sanjaya, I Putu Sugiartha and Lorita Young. (2012) "Voluntary disclosure and earnings management at bank companies listed in Indonesia stock exchange". Journal ChinaUSA Business Review. 11 (3), 368-374

Shin, Yong-Chul and Weimin Wang. (2012) "Dicretionary accruals, insider trades, and the break of good earnings strings". Journal of Business and Economic Studies. 18 (2), 26-91

Surat Edaran Bank Indonesia Nomor 15/ 41/ DKMP perihal perhitungan giro wajib minimum sekunder dan giro wajib minimum berdasarkan loan to deposit ratio dalam Rupiah

Syahfandi, Rizky and Siti Mutmainah. (2012) Faktor-faktor yang mempengaruhi perataan laba penyisihan penghapusan aktiva produktif: praktik manajemen laba pada perbankan syariah di Indonesia. eprints.undip.ac.id

Taktak, Neila Boulila, Sarra Ben Slama Zouari, and Abdelkader Boudriga. (2010) "Do Islamic banks use loan loss provisions to smooth their results?". Journal of Islamic Accounting and Business Research. 1 (2), 1-8

Tobing, Wilson R. L. and Nur Ika Anggorowati. (2009) "Perataan laba melalui penyisihan penghapusan aktiva produktif sektor perbankan". Jurnal Akuntabilitas. 9 (1), 50-62

Yang, Chi-Yih, Hung-Neng Lai, and Boon Leing Tan. (2014) "Managerial ownership structure and earnings management". Journal of Financial Reporting and Accounting. 6 (1), 35-53

Zoubi, T. A. and Al-Khazali O. (2007) "Empirical testing of the loss provisions of banks in the Gulf Cooperation Council region". Journal Managerial Finance. 33 (7), 500511

Zuliyanto, Arief. (2013) "Pengungkapan sukarela mengenai informasi perkiraan pendapatan dan nilai perusahaan dalam industri perbankan". Jurnal Keuangan dan Bisnis. 5 (3), 227-238 